\title{
Studies on the Affinity and Selectivity of Tiquizium Bromide (HSR-902), a Novel Spasmolytic Agent, for Muscarinic Receptors
}

\author{
Masafumi OSHITA, Tetsuo OHASHI, Kouji MORIKAWA, \\ Hideo KATO, Yasuo ITO and Ikunobu MURAMATSU* \\ Research Laboratories, Hokuriku Seiyaku Co., Ltd., Katsuyama, Fukui 911. Japan \\ *Department of Pharmacology. Fukui Medical School, Matsuoka, Fukui 910-11. Japan
}

Accepted March 30,1987

\begin{abstract}
The affinity and selectivity of a novel spasmolytic agent, tiquizium bromide (HSR-902), for muscarinic receptors were studied by the radioligand binding technique using ${ }^{3} \mathrm{H}$-quinuclidinyl benzilate. The parameters $\left(K_{1}, n_{H}\right)$ of HSR-902 obtained from competition experiments in cerebral cortex and heart muscarinic receptors showed that HSR-902 was an atropine-type, nonselective muscarinic antagonist. The affinity of HSR-902 toward the stomach and ileal muscarinic receptors was about 3-4 times more potent than atropine.
\end{abstract}

Antimuscarinics are the most widely used therapeutic agents for the treatment of altered gastrointestinal motility (1). Tiquizium bromide (trans-3-(di-2-thienylmethylene) octahydro-5-methyl-2H-quinolizinium bromide, HSR-902) is a new spasmolytic agent, which shows a potent antimuscarinic activity in the gastrointestinal tract in vitro in contrast to its minimal antimuscarinic activity on mydriasis and cholinergically induced salivation in vivo $(2,3)$.

Muscarinic receptors were subdivided into $M_{1}$ and $M_{2}$ receptors (4-6). $M_{1}$ receptors exhibit a high affinity for pirenzepine and exist predominantly in the cerebral cortex and sympathetic ganglia, whereas $M_{2}$ receptors have low affinity for pirenzepine and exist in the heart and ileum. In this report, we examined the affinity and selectivity of HSR902 for muscarinic receptors using the radioligand binding technique.

Male Sprague-Dawley rats (300-450 g) were sacrificed by decapitation, and their brain, heart, stomach smooth muscle and ileal smooth muscle were rapidly removed. The heart was perfused through the aorta with cold saline until the coronary arteries were cleaned of blood. Tissues were homogenized in 40 vols. of buffer $(50 \mathrm{mM} \mathrm{Na} / \mathrm{K}$ phosphate buffer, $\mathrm{pH}$ 7.4) using a Polytron. at setting 7 with two 10 -sec bursts separated by 30 -sec pauses for the cerebral cortex and at setting 8 with three $15-\mathrm{sec}$ bursts separated by 30-sec pauses for other tissues. The homogenates were centrifuged at $27,000 \times \mathrm{g}$ for $20 \mathrm{~min}$. The pellets were washed twice, and the final pellets were resuspended with cold $50 \mathrm{mM} \mathrm{Na} / \mathrm{K}$ phosphate buffer. Protein was determined by the method of Bradford (7) with bovine serum albumin as a standard.

The binding assay was performed using a modification of the method of Yamamura and Snyder (8). The tissues were incubated with $\left\{/-\left({ }^{3} \mathrm{H}\right)\right.$-quinuclidinyl benzilate $\left({ }^{3} \mathrm{H}-\mathrm{QNB}\right.$. $39.4 \mathrm{Ci} / \mathrm{mmol}, \mathrm{NEN})\}$ in a final volume of 5 $\mathrm{ml}$. Incubation was carried out for $60 \mathrm{~min}$ at $37^{\circ} \mathrm{C}$. Nonspecific binding was defined as binding observed in the presence of $1 \% \mathrm{M}$ atropine. Assays contained approximately 10 $\mu \mathrm{g}$ of protein for the cerebral cortex, $100 \mathrm{~kg}$ of protein for the heart and $30 \mu \mathrm{g}$ of protein for the stomach and ileal smooth muscles. The assay was terminated by rapid filtration of samples through GF/B glass fiber filters (Whatman); this was followed immediately by four rapid washes with $5 \mathrm{ml}$ each of ice cold buffer. Filters were removed and allowed to dry before assaying filter-bound radioactivity by liquid scintillation spectrophotometry in $8 \mathrm{ml}$ of Aquasol-2 (NEN). The binding assay was carried out in duplicate or triplicate. 
Table 1. Potencies of drugs inhibiting ${ }^{3} \mathrm{H}-\mathrm{ONB}$ binding

\begin{tabular}{|c|c|c|c|c|c|c|}
\hline \multirow{2}{*}{$\begin{array}{l}\text { Drug } \\
\text { Tissue }\end{array}$} & \multicolumn{2}{|c|}{ HSR-902 } & \multicolumn{2}{|c|}{ Atropine } & \multicolumn{2}{|c|}{ Pirenzepine } \\
\hline & $K_{1}(n M)^{2 t}$ & $\mathrm{nII}^{13}$ & $K_{i}(n M)^{a}$ & $\mathrm{n}_{\mathrm{H}}^{\mathrm{b}}$ & $K_{i}(n M)^{a}$ & $\mathrm{nH}_{\mathrm{H}}^{\mathrm{h}}$ \\
\hline Cerebral cortex & $0.48 \pm 0.05$ & $0.99 \pm 0.04$ & $0.62 \pm 0.04$ & $1.00 \pm 0.03$ & $21.8 \pm 3.77$ & $0.75 \pm 0.06$ \\
\hline Heart & $0.63 \pm 0.10$ & $0.89 \pm 0.05$ & $3.11 \pm 0.35$ & $1.04 \pm 0.04$ & $409.3 \pm 46.3$ & $0.95=0.06$ \\
\hline Stomach & $0.79 \pm 0.12$ & $0.96 \pm 0.04$ & $3.15=0.36$ & $0.96 \pm 0.04$ & - & $\longrightarrow$ \\
\hline Heum & $0.76 \pm 0.13$ & $0.91 \pm 0.02$ & $2.27 \pm 0.20$ & $0.94 \pm 0.04$ & - & \\
\hline
\end{tabular}

The concentration of ${ }^{3} \mathrm{H}$-ONB used was $30 \mathrm{pM}$. a: IC50 values were obtained from displacement curves, and $K_{i}$ values $(n M)$ were calculated from the method of Cheng and Prusoff $(10)$. b: Hill coefficients $\left(n_{H}\right)$ were determined by linear regression. Each value represents the mean \pm 5 .E. of $5-8$ experiments.

In all tissues used in this experiment, specific binding of ${ }^{3} \mathrm{H}-\mathrm{ONB}$ was saturable. and Scatchard analysis indicated a single population of binding sites. The $K_{a}$ and $B_{\max }$ values for ${ }^{3} \mathrm{H}-\mathrm{QNB}$ binding were respectively $16.2 \pm 1.2 \mathrm{pM}, 2.78 \pm 0.4 \mathrm{pmol} / \mathrm{mg}$ protein in the cerebral cortex $(n=5) ; 26.3 \pm 6.4$ $\mathrm{pM}, 161 \pm 13 \mathrm{fmol} / \mathrm{mg}$ protein in the heart $(n=4) ; \quad 32.6 \pm 2.3 \mathrm{pM}, 632 \pm 51 \mathrm{fmol} / \mathrm{mg}$ protein in the stomach $(n=4)$; and $25.1 \pm 2.6$ $\mathrm{pM}, 281 \pm 62 \mathrm{fmol} / \mathrm{mg}$ protein in the ileum $(n=4)$

In order to examine whether HSR-902 can discriminate between $M_{1}$ and $M_{2}$ receptors. we compared the potencies of antagonists in the cerebral cortex and heart (Table 1). The cerebral cortex includes both $M_{1}$ and $M_{2}$ receptors, and the heart includes predominantly $M_{2}$ receptors. Pirenzepine displayed high affinity in the cerebral cortex $\left(K_{1}=21.8 \mathrm{nM}\right)$, where the $n_{k 1}$ value deviated substantially from unity $\left(n_{H}=0.75\right)$. However, in the heart, pirenzepine displayed low affinity $\left(K_{i}=409 \mathrm{nM}\right)$. where the $n_{H}$ value was nearly equal to unity $\left(n_{\mathrm{l}}=0.95\right)$. These results indicated that in the cerebral cortex. there is a high affinity site for pirenzepine $\left(M_{1}\right.$ receptor). In contrast, atropine showed approximately the same affinity in the cerebral cortex and heart, and the $n_{\mathrm{H}}$ values for atropine were equal to unity in both tissues. These results for pirenzepine and atropine were consistent with the previous report (9). The $K_{1}$ value of HSR-902 was $0.48 \mathrm{nM}$ in the cerebral cortex and $0.63 \mathrm{nM}$ in the heart, indicating that HSR-902 has the same affinity in both tissues. Moreover, the $n_{H}$ values of HSR-902 were 0.99 and 0.89 in the cerebral cortex and heart, respectively. Thus, it was shown that HSR-902 can not discriminate muscarinic receptor subtype; that is. HSR902 is an atropine-type. nonselective muscarinic receptor antagonist.

Since HSR-902 acts on the gastrointestinal tract causing spasmolytic effects, the affinity of HSR-902 for the stomach and ileal smooth muscle muscarinic receptors was examined. HSR-902 showed high affinity at these muscarinic receptors; the potency was about 3-4 times more potent than that of atropine in stomach and ileal smooth muscle muscarinic receptors (Table 1 ).

Kubo et al. $(2,3)$ have reported that the antimuscarinic action of HSR-902 in eye and salivary gland is much less potent than that in the gastrointestinal tract. Although in the present study we did not carry out the binding experiments with iris and salivary gland, the pharmacological evidence reported suggests that this drug may show low affinity to the muscarinic receptors of such tissues; this should be confirmed in further studies. In conclusion, the present study clearly shows that HSR-902 is a potent and nonselective muscarinic antagonist in the gastrointestinal tract.

Acknowledgment: The authors thank Tomiko Haneda for secretarial assistance.

\section{References}

1 Ingelfinger, F.J.: Anticholinergic therapy of gastrointestinal disorders. N. Engl. J. Med. 268, 1454-1457(1963)

2 Kubo, S., Morikawa, K., Yamazaki, M., Kasamatsu, S., Koshinaka, E. and Kato, H.: Pharmacological studies on antispasmodics, I. Selec. tivity to antispasmodic activity of diarylmethylene5 -methyl-trans-quinolizidinium bromides. Yaku- 
gaku Zasshi 101, 174-181 (1981) (Abs. in English)

3 Kubo, S., Morikawa, K., Matsubara, I., Yamazaki, M. and Kato, H.: Pharmacological studies on antispasmodics. III. Aritispasmodic activity of 3(di-2-thienylmethylene)-5-methyl-transquinolizidinium bromide (HSR-902) on smooth organs and its organ selectivity. Folia Pharmacol. Japon. 77, 87-98 (1981) (Abs. in English)

4 Hammer, R., Berrie, C.P., Birdsall, N.J.M., Burgen, A.S.V. and Hulme, E.C.: Pirenzepine distinguishes between different subclasses of muscarinic receptors. Nature 283, 90-92 (1980)

5 Hammer, R. and Giachetti, A.: Muscarinic receptor subtypes: $M 1$ and $M 2$ biochemical and functional characterization. Life Sci. 31, 29912998 (1982)

6 Watson, M., Yamamura, H.I. and Roeske, W.R.: A unique regulatory profile and regional distribution of $\left[{ }^{3} \mathrm{H}\right]$ pirenzepine binding in the rat provide evidence for distinct $M_{1}$ and $M_{2}$ muscarinic receptor subtypes. Life Sci. 32, 30013011 (1983)

7 Bradford, M.: A rapid and sensitive method for the quantitation of microgram quantities of protein utilizing the principle of protein-dye binding. Anal. Biochem. 72, 248-254 (1976)

8 Yamamura, H.I. and Snyder, S.H.: Muscarinic cholinergic binding in rat brain. Proc. Natl. Acad. Sci. U.S.A. 71, 1725-1729 (1974)

9 Luthin, G.R. and Wolfe, B.B.: Comparison of $\left({ }^{3} \mathrm{H}\right)$ pirenzepine and $\left({ }^{3} \mathrm{H}\right)$ quinuclidinylbenzilate binding to muscarinic cholinergic receptors in rat brain. J. Pharmacol. Exp. Ther. 228, 648-655 (1984)

10 Cheng, Y.C. and Prusoff, W.H.: Relationship between the inhibition constant $\left(K_{1}\right)$ and the concentration of inhibitor which causes 50 percent inhibition $\left(I_{50}\right)$ of an enzymatic reaction. Biochem. Pharmacol. 22, 3099-3108 (1973) 